\title{
Honey bee (Apis mellifera) strains differ in avocado (Persea americana) nectar foraging preference
}

\author{
Arnon DAG ${ }^{\mathrm{a}}$, A. Elizabeth FETSCHER ${ }^{\mathrm{b}}$, Ohad AFIK ${ }^{\mathrm{c}}$, Yelena YESELSON ${ }^{\mathrm{d}}$, Arthur \\ SCHAFFER $^{\text {, }}$, Yossi KAMER ${ }^{\mathrm{a}}$, Nicholas M. WASER ${ }^{\mathrm{b}}$, Monica A. MADORE ${ }^{\mathrm{e}}$, Mary Lu \\ ARPAIA $^{\mathrm{e}}$, Reuben HOFSHI ${ }^{\mathrm{f}}$, Sharoni SHAFIR ${ }^{\mathrm{c} *}$ \\ a Institute of Animal Science, Volcani Center, Ministry of Agriculture and Rural Development, PO Box 6, \\ Bet Dagan 50250, Israel \\ b Department of Biology, University of California, Riverside, CA 92521, USA \\ ${ }^{\mathrm{c}}$ B. Triwaks Bee Research Center, Department of Entomology, Faculty of Agricultural, Food and Environmental \\ Quality Sciences, The Hebrew University of Jerusalem, Rehovot 76100, Israel \\ d Department of Vegetable Crops, Volcani Center, Ministry of Agriculture and Rural Development, PO Box 6, \\ Bet Dagan 50250, Israel \\ e Department of Botany and Plant Sciences, University of California, Riverside, CA 92521, USA \\ ${ }_{\mathrm{f}}$ ww.avocadosource.com
}

(Received 12 February 2002; revised 25 October 2002; accepted 28 November 2002)

\begin{abstract}
Avocado nectar is unusual because it contains perseitol, a 7-carbon sugar alcohol. We compared avocado-nectar collection by commonly used Italian-based (IT) honey bee colonies and New World Carniolan (NWC) colonies introduced in avocado orchards in Israel (IS) and California (CA). In IS, NWC colonies had greater honey yields (1.2-4.3 fold), with a higher perseitol content (1.1-5.4 fold), than IT colonies. Overall, we calculated that NWC bees collected 1.4 to 18.1 times more avocado nectar than IT bees in the IS orchards. In CA, analyses of the crop contents of foragers revealed non-significant strainspecific trends in visitation to avocado flowers that were consistent with those indicated by data from IS. The genetic basis for honey bee differences in visitation to avocado flowers was further supported by the consistently high honey perseitol content of selected colonies over two years. The implications of possible strain-specific difference in avocado-nectar preference are discussed in relation to the use of honey bees for avocado pollination.
\end{abstract}

Apis mellifera / Persea americana / perseitol / pollination / preference

\section{INTRODUCTION}

Avocado (Persea americana Mill.) is native to the tropical and subtropical regions of Central and South America. Cultivars of Guatemalan, Mexican, and West Indian origin have spread, becoming important crops in many tropical and subtropical regions around the world (Bergh, 1986; Davenport, 1986). In its native environment, avocado is visited by a diversity of insect species, many of which perform efficient pollination (Ish-Am et al., 1999). In areas where avocados are grown commercially and native pollinators are absent, honey bees (Apis mellifera L.) are used successfully and almost exclusively for avocado pollination (Davenport, 1986, 1998; Vithanage 1990; Ish-Am and Eisikowitch, 1993; Ish-Am et al., 1999). The importance of honey bees in avocado pollination is

\footnotetext{
* Correspondence and reprints

E-mail: shafir@agri.huji.ac.il
} 
evident from the strong positive correlation between bee activity in an orchard and fruit set and yield (Vithanage, 1990; Ish-Am and Eisikowitch, 1992, 1998; Ish-Am, 1994; Robbertse et al., 1998). However, inadequate pollination is still common in avocado, even when bee hives are placed in an orchard, and this is certainly related to the honey bees' preference for flower species other than avocado (Bergh, 1967, 1969; Gazit, 1977; Vithanage, 1990; Ish-Am, 1994; Ish-Am and Eisikowitch, 1998). It is not clear why the avocado is not very attractive to honey bees, since it produces large amounts of sugar-rich nectar. Per hectare, the total sugar production is similar to that of citrus (Ish-Am and Eisikowitch, 1998).

Several honey bee genetic traits, which may be related to their effectiveness as pollinators, have been reported. These include a reduction in flight range, which reduces the impact of competing flora (Gary and Witherell, 1977); the tendency to collect pollen, which is an important characteristic in crops that are pollinated mainly by pollen gatherers (Hellmich et al., 1985; Calderone and Page, 1988; Gordon et al., 1995; Page, 1999); corbicular size (Milne and Pries, 1986; Milne et al., 1986); crop loading (Afik and Shafir, 2001); metabolic rates (Southwick et al., 1990); characteristics that affect flower handling (Alpatov, 1948; Mackensen and Nye, 1966); and preferences for certain crops over competing flora (Nye and Mackensen, 1968, 1970; Basualdo et al., 2000). Such traits, among others, may affect overall foraging preferences, though successful selection regimes may not always prove effective when applied commercially (Gary et al., 1978).

In Southern CA, New World Carniolan (NWC) honey bees introduced into an avocado orchard were observed to be very active on avocado flowers, even though abundant competing vegetation was in bloom in the surrounding area. Such levels of foraging were not observed on nearby farms, where mainly the IT strain of honey bees was employed (R. Hofshi, personal observation). These observations prompted us to test whether the preference of the NWC strain for avocado nectar is greater than that of some other commonly used honey bee strains. Due to genotype-environment interactions, the performance of the different strains may differ in different environments. We therefore conducted the comparisons in several locations in California and Israel.

The NWC strain is the result of an ongoing closed-population breeding program whose base population is derived from the Carniolan race of European honey bee (Cobey and Lawrence, 1988; Cobey, 1999). This strain has been selected based on several traits, including reduced stinging behavior, reduced tendency to swarm, increased honey production, hygienic behavior and resistance to tracheal mites.

Avocado nectar is unusual because it contains perseitol, a 7-carbon sugar alcohol (Liu et al., 1995, 1999). Perseitol has been found in the nectar of all cultivars tested to date, constituting as much as $6 \%$ of the nectar sugars in the Ettinger cultivar. Perseitol has not been found in the nectar of plants that commonly compete with avocado for honey bee visits, such as citrus and wild mustard flowers (Ish-Am, 1994). This unique characteristic offers a tool for indirectly assessing the nectar-foraging activity of honey bees on avocado bloom by testing for the presence of perseitol in the crops of individual bees and by measuring the concentration of perseitol in the honey produced by colonies.

\section{MATERIALS AND METHODS}

\subsection{Israel field study}

\subsubsection{Site description}

Avocado pollination was studied in Israel during the 1999-2000 growing season in two orchards in the Upper Galilee: Kibbutz Dan (IS1: $33^{\circ} 6^{\prime} \mathrm{N}$, $35^{\circ} 24^{\prime} \mathrm{E}, 200 \mathrm{~m}$ above sea-level) and Kfar Giladi

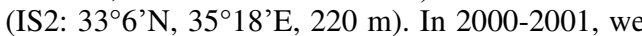
repeated the study in the same two orchards and in an additional two orchards near the Sea of Galilee: Ein Sayeed (IS3: $32^{\circ} 24^{\prime} \mathrm{N}, 35^{\circ} 24^{\prime} \mathrm{E}, 20 \mathrm{~m}$ ) and Shaar Hagolan (IS4: $32^{\circ} 24^{\prime} \mathrm{N}, 35^{\circ} 18^{\prime} \mathrm{E},-200 \mathrm{~m}$ ). The first two orchards measured approximately 45 ha each while the 3rd and 4th measured 22 and 14 ha, respectively. All 4 orchards were planted mainly with 'Ettinger' cultivar. Other cultivars in the orchards were 'Pinkerton', 'Fuerte', and 'Reed'. Orchards IS1 and IS4 were adjacent to large citrus groves (mainly grapefruit). Fields of wildflowers (mainly Brassicaceae) surrounded orchards IS2 and IS3. 


\subsubsection{Colony management}

We established colonies of NWC honey bees using mated queens imported from Kona Farms Apiary (Hawaii), which is supplied yearly with sperm of NWC drones from the breeding program at Ohio State University. We imported stock of honey bees from Australia produced from a breeder line considered to be Apis mellifera ligustica (IT). The mated queens were introduced into queenless colonies (1999-2000: $\mathrm{N}=35$ colonies for each strain; 2000-2001: $\mathrm{N}=70$ colonies for each strain) in October of each year, after marking them on the thorax and clipping one wing. Colonies were kept in areas that were remote $(>3 \mathrm{~km})$ from avocado orchards in order to avoid any possible early conditioning of the foragers to avocado blooms.

In February of each year, we assessed the brood and adult population of the colonies. Brood area was estimated by dividing each side of each comb into eight parts $\left(10 \times 10 \mathrm{~cm}\right.$ squares; $\left.\mathrm{dm}^{2}\right)$, and assessing the number of such squares of open and sealed brood. Adult population size was estimated by counting the number of frames covered with bees. In early April, at the beginning of the avocado bloom, we chose 13-18 colonies of each strain for introduction to each of the different sites so that, at each site, the colonies had similar brood and adult populations. In 2000, the mean brood area of the NWC and IT colonies was 0.28 and $0.27 \mathrm{~m}^{2}$, respectively, and the mean number of bee-covered frames was 4.9 in the colonies of both strains. In 2001, the mean brood area of the NWC and IT colonies that were later introduced into IS1 and IS2 was 0.53 and $0.58 \mathrm{~m}^{2}$, respectively, and the mean number of bee-covered frames was 8.2 and 7.8. For the colonies that were later introduced into IS3 and IS4, the corresponding values were 0.23 and $0.29 \mathrm{~m}^{2}$, and 4.4 and 5.0 bee-covered frames, respectively.

We kept colonies that had outstanding high and low honey perseitol levels in the first year, in order to test them again the following year. In the second season, we selected from the outstanding colonies four high (range: 1.46-2.16\% perseitol) and four low (0.41-0.98\%) colonies in which we confirmed that the original queens were present. We placed these eight colonies at IS1 together with the other colonies that were used in the experiment.

\subsubsection{Honey harvest}

After the colonies had been introduced into the orchards in early April, we added a second super to each hive, above a queen excluder. We collected the honey supers at the end of April of each year, after the citrus and early-blooming avocado cultivars (i.e. 'Ettinger', 'Pinkerton', and 'Fuerte') had finished blooming. We weighed each super before and after extracting the honey from the combs. We extracted the honey from each beehive separately, using a two-frame manual honey extractor, and kept a $0.5 \mathrm{~kg}$ sample from each colony for analysis of perseitol contents.

\subsection{California field study}

\subsubsection{Site description}

We worked simultaneously in Israel and California (USA). The study was conducted in 1999-2000 in two avocado orchards in southern CA: Fallbrook, in northern San Diego County (CA1: $33^{\circ} 27^{\prime} \mathrm{N}, 117^{\circ} 20^{\prime} \mathrm{W}, 275 \mathrm{~m}$ ) and Somis in inland Ventura County (CA2: $34^{\circ} 8^{\prime} \mathrm{N}, 119^{\circ} 5^{\prime} \mathrm{W}$, $79 \mathrm{~m})$. CA1 measured approximately $200 \mathrm{ha}$, and CA2 was 15 ha. The orchards were planted mainly with 'Hass' cultivar and other cultivars were 'Zutano', 'Ettinger', 'Bacon', 'Gwen', 'Walter Hole', and 'Pinkerton'. CA1 was adjacent to a 6-ha citrus grove (mainly grapefruit) and approximately 80 ha of commercial flower production within $1.5 \mathrm{~km}$ of the apiaries. This orchard was surrounded by wildflowers, including wild mustard (Brassica nigra), wild radish (Raphanus sativus), deerweed (Lotus scoparius), lupine (Lupinus sp.), California lilac (Ceanothus sp.), and California buckwheat (Eriogonum fasciculatum), all of which can potentially compete with avocado bloom for honey bee visitation. CA2 was surrounded by a large citrus grove (mainly lemon), and by strawberries, vegetables, and cut flowers, which are not strong competitors for honey bee visitations. Hence, citrus was the main competitor with avocado bloom for bee visitation in CA2.

\subsubsection{Colony management}

The queens in the CA colonies had been artificially inseminated. Glenn Apiaries (Fallbrook, CA) supplied the initial stock of queens for both the NWC and IT strains, and Susan Cobey of Ohio State University supplied NWC semen. We introduced the queens into the hives between September 1999 and February 2000. In February 2000 we chose 15 colonies of each strain for introduction to the CA1 orchard and 14 colonies of each strain for introduction to the CA2 orchard. Only hives with at least six frames of bees were used in the study.

\subsubsection{Collection of returning foragers}

In both CA sites, we caught individual bees of each strain on their way back to their hives and 
analyzed the contents of their crops for the presence of perseitol. We sampled bees on 5-10 May in CA1, and 25, 26, and 31 May and 1 June in CA2. On each day of the study, we sampled bees between 0900h and $1700 \mathrm{~h}$ (local time) from an equal number of randomly selected hives of each strain. The strain of bee sampled was alternated on a hive-by-hive basis throughout the day. For each hive, we captured returning foragers at the hive entrance with an insect net and anaesthetized them briefly with $\mathrm{CO}_{2}$. Their abdomens were then gently squeezed to purge the contents of their crops. Small amounts of the nectar they had collected were sampled and measured using Drummond ${ }^{\circledR}$ (Drummond Scientific Co., Broomall, PA, USA) glass microcapillary tubes of $2,5,10$, or $20 \mu \mathrm{L}$ capacity, depending on the volume of the sample. These samples were diluted in water and analyzed by HPLC to ascertain the presence of perseitol. In addition, at CA2, the remaining volume of the crop contents of each forager was measured.

\subsection{Laboratory analyses}

\subsubsection{Honey}

Approximately $200 \mathrm{mg}$ of each honey sample collected in Israel was solubilized in $1.5 \mathrm{~mL}$ double-distilled water at $70{ }^{\circ} \mathrm{C}$ for $2 \mathrm{~h}$. The sample was vortexed vigorously and filtered through a $0.2-\mu \mathrm{m}$ Nylon filter prior to HPLC analysis. Soluble sugars were separated using an Alltech $700 \mathrm{CH}$ carbohydrate column $(300 \times 6.5 \mathrm{~mm})$ at $90{ }^{\circ} \mathrm{C}$, as described in Schaffer et al. (1991). The mobile phase consisted of double-distilled water at a flow rate of $0.5 \mathrm{~mL} / \mathrm{min}$, and detection was performed by differential refraction on a Shimadzu RID-10A system. A standard solution containing $0.25 \%$ (w/v) each of sucrose, glucose, fructose, and perseitol was used to identify and quantify the individual sugar components in the honey samples.

\subsubsection{Crop loads}

For crop samples in CA, between 1 and $10 \mu \mathrm{L}$ (depending on availability) of the crop contents of each forager captured upon her return to the hive was collected, measured, and added to $100 \mu \mathrm{L}$ of double-distilled water. The solution was agitated briefly, then frozen quickly on dry ice in the field. An additional $40 \mu \mathrm{L}$ of water was added to each sample in the laboratory. Twenty $\mu \mathrm{L}$ was removed and injected onto a Whatman Sugar Pak 1 column at $85^{\circ} \mathrm{C}$ and a flow rate of $0.6 \mathrm{~mL} / \mathrm{min}$ using $50 \mathrm{mg} / \mu \mathrm{L}$ CaEDTA as eluant connected to a Beckman Isocratic HPLC system. Sugars were quantified by Refractive Index detection and comparison to authentic perseitol.

\subsection{Statistical analyses}

In Israel, we tested the effects of site and strain and their interaction on percent perseitol content (arcsine square-root-transformed) and on honey yield in each season separately by 2-way ANOVAs. We used backward elimination of predictors with a retention criterion of $\alpha<0.05$ to select a final model (see Aldrich and Nelson, 1984). In CA, differences between the number of bees of each strain visiting or not visiting avocado (according to the presence of perseitol in their crop) were analyzed using a chi-square test statistic. Crop volume was analyzed by a two-way ANOVA, with the data square-root transformed, as this method was more effective than a Log transformation at improving homoscedasticity of model residuals (Sokal and Rolf, 1995).

\section{RESULTS}

\subsection{Honey yield}

\subsubsection{Spring 2000}

Honey yields differed between the 2 sites $(F=5.85, \mathrm{df}=1,52, P=0.019)$ and the 2 strains $(F=15.0, \mathrm{df}=1,52, P=0.0003)$, and the site $\mathrm{x}$ strain interaction was not significant $(F=0.04$, df $=1,51, P=0.84)$. The mean honey yield of the NWC bees at IS1, $17.5 \mathrm{~kg}$, was almost twice that of the IT bees, $9.9 \mathrm{~kg}$. Similarly, the honey yield of the NWC bees at IS2, $13.7 \mathrm{~kg}$, was greater than that of the IT bees, $8.2 \mathrm{~kg}$.

\subsubsection{Spring 2001}

There was a significant race $\times$ site interaction $(F=9.51$, df $=3,94, P<0.0001)$. Contrasts between the NWC and IT colonies at each site revealed that the honey yields of the former were significantly greater in 3 of the 4 sites. Mean honey yields of the NWC and IT colonies were 15.6 and $10.8 \mathrm{~kg}$ in IS1 $(t=2.59, P=0.01), 18.8$ and $15.4 \mathrm{~kg}$ in IS2 $(t=0.96, P=0.34), 9.1$ and $2.9 \mathrm{~kg}$ in IS3 $(t=7.79, P<0.0001)$, and 6.8 and $1.6 \mathrm{~kg}$ in IS4 $(t=5.55, P<0.0001)$. 


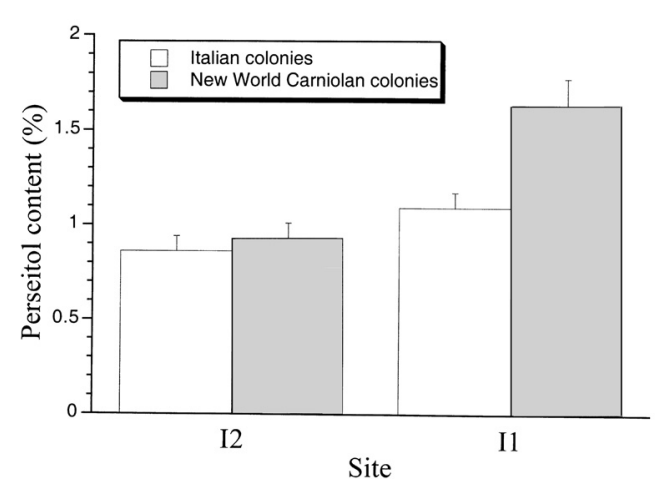

Figure 1. Effect of site and strain of bees on perseitol content $(\%$; mean + SE) of honey samples from colonies placed in 2 avocado orchards in Israel in 2000.

\subsection{Honey perseitol content}

\subsubsection{Spring 2000}

Perseitol content in the honey samples ranged from $0.41 \%$ to $2.43 \% \mathrm{w} / \mathrm{w}$. The site $\times$ strain interaction was not significant $(F=3.18$, $\mathrm{df}=1,52, P=0.08)$ and was removed from the model. Perseitol content was higher at IS1 than at IS2 $(F=19.9, \mathrm{df}=1,53, P<0.0001)$, suggesting that wildflowers competed more strongly than citrus flowers with the avocado bloom. Percent perseitol composition of the honey was higher in the NWC colonies than in the IT colonies $(F=5.85$, df $=1,53, P=$ $0.019)$, supporting the hypothesis that NWC bees visited more avocado blooms (Fig. 1).

\subsubsection{Spring 2001}

Perseitol content in the honey samples ranged from $0.01 \%$ to $2.3 \%$ (Fig. 2). The effect of both site $(F=8.66, \mathrm{df}=3,94, P<$ $0.0001)$ and strain $(F=72.1, \mathrm{df}=1,94, P<$ $0.0001)$ was significant, and there was also a significant site $\times$ strain interaction $(F=9.51$, df $=3,94, P<0.0001)$. The perseitol content in the NWC colonies was greater than in the IT colonies. The difference was especially great at IS4 and at IS3, with NWC colonies having 4-5 times greater perseitol levels than IT colonies.

The "high" colonies from the 2000 season were ranked in the top five of the 34 colonies

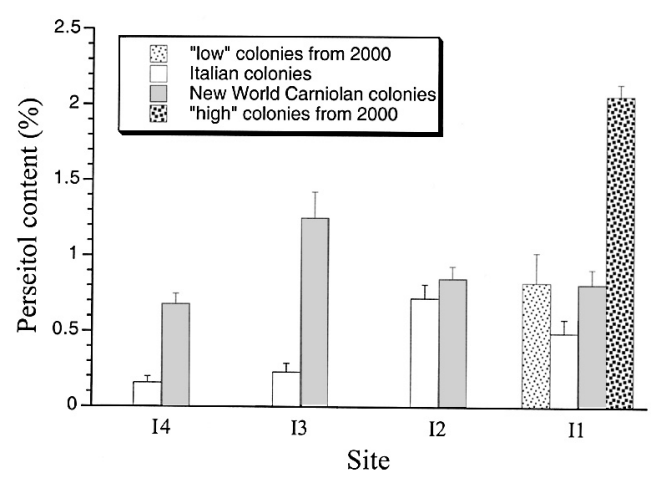

Figure 2. Effect of site, strain of bees and year on perseitol content $(\%$; mean $+\mathrm{SE})$ of honey samples from colonies placed in 4 avocado orchards in Israel in 2001.

at that location in honey perseitol, with significantly higher levels than the other colonies introduced in $2001(t=5.53, \mathrm{df}=28$, $P<0.0001)$. The "low" colonies from the 2000 season showed intermediate, and variable, honey perseitol, that was similar to that of the colonies introduced in 2001 $(t=0.90, \mathrm{df}=28, P=0.38)$. The "high" colonies in the 2001 season also had again significantly greater honey perseitol levels than the "low" hives $(t=4.58$, df $=6, P=$ $0.004)$.

\subsection{Visitation to avocado by individual bees}

Trends from the CA portion of the study corroborated the honey analyses in Israel. At CA2, where avocado bloom was in competition with citrus, $32 \%$ of NWC foragers caught upon their return to their hives had visited avocado flowers, compared to $22 \%$ of IT foragers ( $\mathrm{N}=60$ for both types). In CA1, where the avocado orchard was surrounded by wildflowers, fewer of the bees examined visited avocado relative to CA2 (18\% of NWC, $\mathrm{N}=50$ vs. $21 \%$ of IT, $\mathrm{N}=52$ ). The significance of the effects of the location of the orchard and the strain of honey bee was tested using the presence/absence of perseitol in the crop of returning foragers as a binary response variable in a multiple logistic regression. When the full model was run (with "site" and "strain" as the main effects), the interaction term was non-significant (Wald $\chi^{2}=1.2$, 


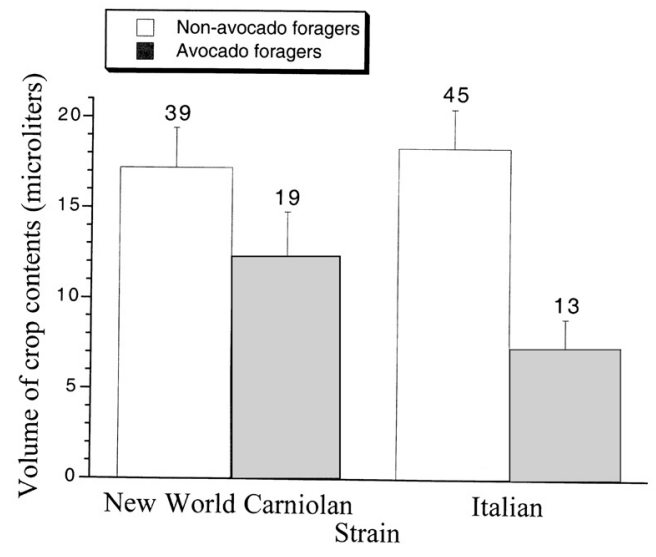

Figure 3. Total volume of crop contents $(\mu \mathrm{L}$; mean $+\mathrm{SE}$ ) of foragers caught upon return to their hives from Italian (IT) and New World Carniolan (NWC) colonies placed in a California avocado orchard (CA2), in 2000. Numbers above the error bars are the sample size. The type of bloom visited by a given forager was inferred by the presence or absence of perseitol in the crop sample.

df $=1, P>0.3)$ and was therefore removed. Even in the model without the interaction, neither of the two main effects was a significant predictor of the presence of perseitol in the crop of returning foragers (site: Wald $\chi^{2}=1.5$, $\mathrm{df}=1, P>0.2$; strain: Wald $\chi^{2}=0.4$, df $\left.=1, P>0.5\right)$.

In CA2, we measured the crop volume of all foragers captured. Foragers of both strains that had visited avocado flowers had lower crop volumes than those that had visited other nectar sources, as determined by the absence of perseitol in the crop sample (Fig. 3). The volume of the crop content of NWC foragers returning from avocado was $30 \%$ lower than that of bees that had visited other nectar sources, while IT foragers exhibited an even greater reduction $(58 \%)$ in volume of their crop content when returning from avocado, as compared to those returning from other nectar sources. A fully factorial ANOVA was used to examine the effects of honey bee strain and nectar source (avocado vs. non-avocado) on crop volume. First, in order to remove any effect of the hive from which bees were collected on the volume of nectar in their crops, a one-way ANOVA using "hive" as a random effect and square-root-transformed crop volume as the dependent variable was run. The residuals from this analysis were then used as the response variable in the fully factorial model, with "strain" and "nectar source" as fixed effects. The interaction term was non-significant $(F=0.7, \mathrm{df}=1, P>0.4)$ and was removed. In the subsequent model containing only the two main effects, "nectar source" was a significant predictor of crop volume $(F=5.2$, df $=1, P=0.02)$, whereas "strain" was not $(F=0.3$, df $=1, P>0.6)$.

\section{DISCUSSION}

Honey bee foraging decisions are affected by characteristics of individuals (e.g., age and experience) and colonies (e.g., population density and food stores). Differences between strains such as those detected here between NWC and IT bees in nectar foraging, at the individual and colony levels, also suggest genetic components of behaviors (Alpatov, 1948; Danka and Rinderer, 1986; Dietz, 1992). NWC bees may be especially attracted to avocado floral odors, to the unique sugar composition of its nectar, or to other characteristics of its bloom (Baker and Baker, 1983), and these differences may be genetic. The significance of genetics has been highlighted by the success of selection regimes that produce, in a few generations, lines differing in several behaviors that affect foraging (Nye and Mackensen, 1968, 1970; Gary and Witherell, 1977; Hellmich et al., 1985; Calderone and Page, 1988; Gordon et al., 1995; Hunt et al., 1995; Page et al., 1998, 2000). An important component of a successful selection regime is having a reliable and quantifiable trait on which to select (Page, 1999). A reliable measure of avocado-nectar content in honey and crop samples is its perseitol content. We took advantage of this unique characteristic of avocado nectar to assess the relative amount of visitation to avocado flowers by nectar foragers of the two strains.

The honey of NWC hives had significantly greater proportions of perseitol than honey of IT hives during both years, supporting a genetic component to preference of avocado bloom (Figs. 1 and 2; Tab. I). These colonylevel differences resembled the individuallevel differences observed in CA. At each site, the relative difference between the strains in 
Table I. Comparison between New World Carniolan (NWC) and Italian (IT) colonies in spring honey yield and in the proportion of perseitol in the honey. Values are the ratio of those in the NWC colonies divided by those of the IT colonies. The compounded effect is the product of the honey yield ratio multiplied by the ratio of honey perseitol content and represents the total increase in nectar foraging activity on avocado of NWC colonies relative to that of IT colonies.

\begin{tabular}{lcccccc}
\hline Year & \multicolumn{2}{c}{2000} & \multicolumn{5}{c}{2001} \\
\hline Site & IS1 & IS2 & IS1 & IS2 & IS3 & IS4 \\
\hline Honey yield ratio & 1.77 & 1.67 & 1.44 & 1.22 & 3.14 & 4.25 \\
Ratio of honey perseitol content & 1.50 & 1.08 & 1.65 & 1.18 & 5.4 & 4.25 \\
Compounded effect & 2.65 & 1.80 & 2.38 & 1.44 & 16.94 & 18.06 \\
\hline
\end{tabular}

honey perseitol proportions remained similar across the two years (Tab. I). This further supports the influence of a genetic component in determining preference to avocado. There is also evidence for a genotype-environment interaction, in that the relative difference between the honey bee strains differed between sites. The open-flower structure of avocado flowers makes them suited for pollination by many species of generalist insects, including different bee species and honey bees, though this Old World species did not evolve with avocado (Ish-Am et al., 1999). Strain-specific differences between honey bees in preference to avocado are, therefore, probably the result of differences in natural (and/or artificial) selection pressures, not connected to avocado, on the various strains.

The NWC colonies also had consistently higher honey yields than the IT colonies (Tab. I). This raises the possibility that the apparent difference between the strains in preference to avocado is a consequence of a more general difference between the strains in honey production (one of the characteristics for which they have been selected (Cobey and Lawrence, 1988)). However, within each site and for each strain and each year, there was no consistent correlation between honey yield and honey perseitol content. Only one of the 12 correlation coefficients was significant (at an experiment-wise alpha of 0.05), with seven having a positive trend and the other five a negative trend. This suggests that the tendency of NWC bees to collect more avocado honey is independent of their tendency to produce greater honey yields.

Despite an overall decrease in honey perseitol levels in 2001 at IS1, colonies selected for their high honey perseitol levels in 2000, maintained high levels also in 2001 compared to the other colonies at that site and compared to colonies selected for low perseitol levels in 2000 (Fig. 2). These consistent differences strongly support our hypothesis of a genetic component for the preference to avocado nectar. Colonies selected for low honey perseitol did not show a lower than average level the following year, possibly reflecting the greater difficulty in reducing the level of a trait that is already relatively low, compared to increasing the level (e.g., Hellmich, 1985).

At CA2, NWC bees foraging on avocado flowers tended to return with greater nectar loads than IT bees (Fig. 3), which could further contribute to a difference between the strains in the amount of avocado honey produced. Indeed, NWC bees in Israel produced more avocado honey at all sites (Tab. I).

Because perseitol content in nectar varies between flowers in their male and female stages, and among cultivars (Ish-Am, 1994; Liu et al., 1995), we cannot precisely determine the amount of nectar collected from avocado based on the honey perseitol analysis. However, assuming a similar distribution of flower visits by bees of both strains in the avocado orchards, the compounded effect would be between 1.44 and 18.06 times more avocado nectar collected by NWC bees (Tab. I).

Regardless of strain, honey bee foragers returning from avocado at CA2 carried significantly smaller nectar loads than foragers returning from the competing flora (Fig. 3). Honey bees often do not return to the hive with full crops. The crop-loading decision is determined by several parameters that affect foraging efficiency (Schmid-Hempel et al., 1985; Kacelnik et al., 1986; Shafir and Afik, 
2001). When returning from more distant nectar sources, bees carry greater loads than when returning from sources near the hive (Kacelnik et al., 1986). At CA2, avocado bloom tended to be the closest forage to the hives. This could explain the observed difference in crop loads between avocado- and non-avocado foragers.

Afik and Shafir (2001) found that honey bees of the Buckfast line collected greater nectar loads than bees of an IT line. Similarly, the individual-bee studies in CA suggest that NWC bees returning from avocado may visit more flowers per trip than IT bees (though the differences were not statistically significant). If this is true, it may mean that NWC bees are more effective cross pollinators than IT bees, as they may move among trees more often than IT bees as a consequence of their tendency to visit more flowers per foraging bout. Cross pollination is an important consideration in avocado due to its peculiar breeding system with A- and B-flowering group cultivars. Effective cross pollination under commercial conditions is carried out mainly by honey bees transferring the pollen from trees of flowering group A to trees of flowering group B and vice versa (Stout, 1923; Gazit, 1977).

In avocado, pollination is achieved primarily by bees that collect nectar, because nectarcollecting bees visit flowers during their female phase as well as during the male phase. Bees that collect only pollen visit only male flowers and therefore do not pollinate femalephase flowers (Ish-Am and Eisikowitch, 1993, 1998). Thus, unlike crops in which the pollen source collected by the colony is a reliable indicator of effective pollination activity (e.g., apple - Stern et al., 2001), in avocado the nectar sources of the colony offer a good perspective of the colony's contribution to avocado pollination. We have not followed individual foragers, but honey bees tend to make short visits to avocado flowers, with handling times of 2-10 s (Ish-Am and Eisikowitch, 1993), suggesting that individuals visit many flowers per foraging trip. Future studies in which foragers of the two strains are followed in the field (e.g., Gary et al., 1978) should prove especially informative for understanding their pollination effectiveness. In particular, it is important to study the movement of honey bees between different cultivars to assess their effectiveness in cross-pollination.

The greater tendency of NWC bees to collect avocado nectar over IT bees suggests a genetic component to this behavior and argues that these bees may be more effective pollinators of avocado, at least in some environments. If this is the case, a selection program that acts on the considerable variation observed between colonies should be able to produce a honey bee strain with an even stronger preference for avocado flowers than the average preference of the NWC bees at present.

\section{ACKNOWLEDGEMENTS}

We thank the beekeepers who operated the various apiaries in which this study was conducted for their generous cooperation. This research was partly funded by Research Grant No. US-3345-02R from BARD, the United States - Israel Binational Agricultural Research and Development Fund (M.L.A., S.S. and A.D), by Israel Ministry of Agriculture grant \# 824-0101-02 (S.S and A.D.), grants from the California Avocado Commission (A.E.F. and N.W.), and a fellowship of the Israel Fruit Board (O.A).

Résumé - Les souches d'abeilles domestiques (Apis mellifera) ont des préférences variables vis-à-vis du nectar d'avocat (Persea americana). L'avocat (Persea americana Mill), plante indigène des régions tropicales et subtropicales des Amériques centrale et du Sud, est une culture alimentaire importante dans de nombreuses régions du monde. L'Abeille domestique européenne est le plus important pollinisateur de l'avocat là où il n'est pas indigène et des travaux antérieurs ont montré une forte corrélation positive entre l'activité des abeilles, la production de fruits et le rendement en avocats. Une mauvaise pollinisation est encore commune même lorsque des ruches d'abeilles sont placées dans le verger, vraisemblablement parce que les butineuses préfèrent les fleurs d'autres espèces à celles de l'avocat.

D'autres études ont montré qu'il existe des différences entre races d'abeilles qui peuvent influer sur leur efficacité en tant que pollinisateurs. Nous avons comparé l'efficacité des carnoliennes du Nouveau Monde (NWC) à celle d'une souche classique considérée comme italienne (IT). Cette comparaison a été suggérée par des observations faites sur le terrain en California (CA) montrant que les NWC visitaient les fleurs d'avocat à un taux plus élevé que les abeilles IT. Nous avons été aidés dans cette recherche par une caractéristique unique du nectar d'avocat : il renferme un polyol à 7 carbones, le perséitol (PSL) que nous avons pu détecter dans 
le jabot de l'abeille et dans le miel produit par la colonie par analyse en HPLC. Cela a permis de vérifier indirectement l'activité du butinage de nectar par les abeilles sur les fleurs d'avocat.

Nous avons comparé la visite des abeilles IT et NWC en divers lieux en Israël (IS) durant deux saisons et en Californie (CA) durant une saison. En Israël, les colonies NWC avaient des rendements en miel plus élevés avec une teneur en PSL plus élevée que les colonies IT. Au total nous estimons que les abeilles NWC ont récolté 1,4 à 18,1 fois plus de nectar d'avocat que les IT en Israël. La différence relative de proportion de PSL dans le miel entre les lignées est restée semblable au cours des 2 années. En Californie nous avons échantillonné les jabots d'abeilles IT et NWC comme elles rentraient à la ruche. L'analyse a montré des tendances non significatives spécifiques de la lignée concernant la visite des fleurs d'avocat. Ces résultats sont cohérents avec les données d'Israël. D'une manière générale les abeilles NWC butinant l'avocat avaient tendance à rentrer avec de plus lourdes charges de nectar que les italiennes.

L'étude en Israël a aussi entamé un programme de sélection utilisant les colonies des deux races qui avaient en 2000 la teneur du miel en PSL la plus forte et la plus faible. Les différences révélées par cette étude entre abeilles NWC et IT, tant au niveau individuel qu'au niveau de la colonie, permettent d'affirmer qu'il existe une composante génétique du comportement de butinage et de la préférence du nectar d'avocat. Nos résultats suggèrent qu'en poursuivant la sélection il est possible d'obtenir une lignée d'abeilles ayant une préférence encore plus grande pour les fleurs d'avocat que les actuelles NWC. Cela aiderait les producteurs d'avocat du monde entier en leur offrant de meilleures chances de pollinisation et donc un potentiel de production accru.

\section{Apis mellifera / Persea americana / perséitol / pollinisation / préférence}

\footnotetext{
Zusammenfassung - Unterschiedliche Sammelpräferenz von Zuchtlinien der Honigbiene (Apis mellifera) für Avocadonektar (Persea americana). Die in tropischen und subtropischen Regionen von Südamerika beheimatete Avocado (Persea americana Mill.) wird in vielen Weltregionen als wichtige Nahrungspflanze kultiviert. Außerhalb ihres natürlichen Verbreitungsgebietes ist die Europäische Honigbiene (HB) der wichtigste Bestäuber von Avocado. In früheren Untersuchungen konnte eine deutliche Beziehung zwischen Bienenaktivität, Fruchtansatz und Avocadoertrag festgestellt werden. Dennoch ist unzureichende Bestäubung verbreitet, selbst wenn Bienenvölker in der Avocadopflanzung aufgestellt werden, möglicherweise weil HB Sammlerinnen andere Blüten der Avocado vorziehen.
}

Einige Studien hatten gezeigt, dass verschiedene Unterarten der Honigbiene Unterschiede aufweisen, die sich auf ihre Leistung als Bestäuber auswirken könnten. Wir wollten die Bestäubungsleistung von Carnicabienen aus der Neuen Welt (NWC) mit der einer verbreiteten und als Italienische Bienen bezeichneten Zuchtlinie (IT) vergleichen. Dieser Vergleich wurde durch Freilandbeobachtungen in Kalifornien ausgelöst, bei denen NWC Bienen häufiger als IT Bienen Avocadoblüten besucht hatten. Wir ließen uns in unserer Untersuchung durch ein besonderes Merkmal des Avocadonektars leiten, der Perseitol, einen 7-karbonischen Zuckeralkohol enthält. Wir konnten diesen Zucker sowohl im Honigmagen der Sammlerinnen als auch in dem Honig aus dem Volk mit einer HPLC-Analyse nachweisen; hierdurch konnten wir die Besuchsaktivität von Avocadoblüten auf indirekte Weise abschätzen.

Wir verglichen in zwei Jahren die Besuchshäufigkeit bei IT und NWC Bienen an verschiedenen Orten von Israel (IS) und in einem weiteren Jahr in Kalifornien (CA). In IS hatten NWC Völker einen höheren Honigertrag verbunden mit einem höheren Gehalt an Perseitol als die IT Völker. Im Ganzen gesehen schätzen wir, dass NWC Bienen in den IS Pflanzungen 1,4 bis 18,1 mal mehr Avocadonektar sammelten. Der relative Unterschied zwischen den Bienenlinien im PSL Anteil des Honigs war in beiden Untersuchungsjahren ähnlich. In den CA Pflanzungen sammelten wir den Honigmageninhalt von zurückkehrenden Sammlerinnen. Die Analyse zeigte nichtsignifikante Unterschiede im Blütenbesuch, die mit den Untersuchungen in Israel konsistent waren. Insgesamt hatten die aus den Avocadopflanzungen zurückkehrenden NWC Bienen einen tendenziell größeren Honigmageninhalt als die IT Bienen.

In der IS Studie wurde ein Selektionsprogramm begonnen, basierend auf Völkern beider Unterarten mit besonders hohem oder besonders niedrigem PSL Honiggehalt im Jahr 2000. Die auf hohen PSL ausgelesenen Völker behielten ihren Rangplatz im Jahr 2001, relativ zu den anderen Völkern und insbesondere zu denen auf niedrigen PSL ausgelesenen Völker. Der in dieser Studie sowohl bei Einzelbienen als auch auf Volksebene aufgedeckte Unterschied im Nektarsammeln von NWC und IT Bienen stützt die Annahme, dass Sammelverhalten und Präferenz für Avocadonektar eine genetische Komponente enthält. Unsere Ergebnisse deuten darauf hin, dass im Verlaufe weiterer Selektion eine Zuchtlinie mit noch stärkerer Präferenz für Avocado möglich sein könnte. Ein Erfolg wäre durch die bessere Bestäubungsleistung und die damit erhöhte Produktivität hilfreich für Avocadozüchter weltweit.

Apis mellifera / Persea americana / Perseitol / Bestäubung / Bevorzugung 


\section{REFERENCES}

Afik O., Shafir S. (2001) Effect of ambient temperature on crop load size in honeybees, Phytoparasitica 29, 80 (abstract).

Aldrich J.H., Nelson F.D. (1984) Linear probability, logit, and probit models, Sage Publications, Beverly Hills, California.

Alpatov V.V. (1948) Bee races and red clover pollination, Bee World 29, 61-63.

Baker H.G., Baker I. (1983) A brief historical review on the chemistry of floral nectar, in: Bentley B., Elias T. (Eds.), The biology of nectaries, Columbia University Press, NY, pp. 129-152.

Basualdo M., Bedascarrasbure E., De Jong D. (2000) Africanized honey bees (Hymenoptera: Apidae) have a greater fidelity to sunflowers than European bees, J. Econ. Entomol. 93, 304-307.

Bergh B.O. (1967) Reasons for low yields of avocados, CA Avoc. Soc. Ybk. 51, 161-172.

Bergh B.O. (1969) Avocado, in: Ferwerda F.P., Wit F. (Eds.), Outlines of perennial crop breeding in the tropics, Veenman and Zonen N.V., Wageningen, The Netherlands, pp. 23-51.

Bergh B.O. (1986) Persea americana, in: Halevy A.H. (Ed.), Handbook of flowering, Vol. 5, CRC Press, Boca Raton, FL, pp. 253-268.

Calderone N.W., Page R.E. (1988) Genotypic variability in age polyethism and task specialization in the honey bee, Apis mellifera (Hymenoptera: Apidae), Behav. Ecol. Sociobiol. 22, 17-25.

Cobey S. (1999) The New World Carniolan closed population breeding project, in: Proc. 36th Apimondia Congr. Vancouver, Canada, Apimondia Publ. House, Bucharest, pp. 26-27.

Cobey S., Lawrence T. (1988) Commercial application and practical use of the Page-Laidlaw closed population breeding program, Am. Bee J. 128, 341-344.

Danka R.G., Rinderer T.E. (1986) Africanized bees and pollination, Am. Bee J. 126, 680-682.

Davenport T.L. (1986) Avocado flowering, Hortic. Rev. 8, 257-289.

Davenport T.L. (1998) What if there is no pollinator? Subtrop. Fruit News 6, 15-17.

Dietz A. (1992) Honey bees of the world, in: Graham J.M. (Ed.), The hive and the honey bee, Dadant and Sons, Hamilton, IL, pp. 23-61.

Gary N.E., Witherell P.C. (1977) Distribution of foraging bees of three honey bee stocks located near onion and safflower fields, Environ. Entomol. 6, 785-788.

Gary N.E., Witherell P.C., Lorenzen, K. (1978) The distribution and foraging activities of common Italian and "Hy-Queen" honey bees during Alfalfa pollination, Environ. Entomol. 7, 233240.

Gazit S. (1977) Pollination and fruit set of avocado, in: Saults J.W., Philips R.L., Jackson L.K. (Eds.), Proc., First Int. Trop. Fruit Short Course: the
Avocado, Univ. of Florida, Gainesville, FL, pp. 88-92.

Gordon D.M., Barthell J.F., Page R.E., Fondrk M.K., Thorp R.W. (1995) Colony performance of selected honey bee (Hymenoptera: Apidae) strains used for Alfalfa pollination, J. Econ. Entomol. 88, 51-57.

Hellmich R.L., Kulincevic J.M., Ruthenbuhler W.C. (1985) Selection for high and low pollenhoarding honey bees, J. Hered. 76, 155-158.

Hunt G.J., Page R.E., Fondrk M.K., Dullum C.J. (1995) Major quantitative trait loci affecting honey bee foraging behavior, Genetics 141, 1537-1545.

Ish-Am G. (1994) Interrelationship between avocado flowering and honey bees and its implication on the avocado fruitfulness in Israel, Ph.D. Thesis, Tel-Aviv University, Tel-Aviv, Israel (in Hebrew).

Ish-Am G., Eisikowitch D. (1992) New insight into avocado flowering in relation to its pollination, CA Avoc. Soc. Ybk. 75, 125-137.

Ish-Am G., Eisikowitch D. (1993) The behavior of honey bees (Apis mellifera) visiting avocado (Persea americana) flowers and their contribution to its pollination, J. Apic. Res. 32, 175-186.

Ish-Am G., Eisikowitch D. (1998) Low attractiveness of avocado (Persea americana Mill.) flowers to honey bees (Apis mellifera L.) limits fruit set in Israel, J. Hortic. Sci. Biotech. 73, 195-204.

Ish-Am G., Barrientos-Priego A.F., CastanedaVildozola A., Gazit S. (1999) Avocado (Persea americana Mill.) pollinators in its region of origin, Rev. Chapingo Ser. Hortic. 5, 137-143.

Kacelnik A., Houston A.I., Schmid-Hempel P. (1986) Central-place foraging in honey bees: the effect of travel time and nectar flow on crop filling, Behav. Ecol. Sociobiol. 19,19-24.

Liu X., Sherman G., Robinson P.W., Witney G.W., Arpaia M.L. (1995) Nectar sugar composition of selected avocado cultivars and related species, Subtrop. Fruit News 3, 8-9.

Liu X., Robinson P.W., Madore M.A., Witney G.W., Arpaia M.L. (1999) 'Hass' carbohydrate fluctuations. I. Growth and phenology, J. Am. Soc. Hortic. Sci. 124, 671-675.

Mackensen O., Nye W.P. (1966) Selection and breeding of honeybees for collecting alfalfa pollen, J. Apic. Res. 12, 187-190.

Milne C.P. Jr., Pries K.J. (1986) Honeybees with larger corbiculae carry larger pollen pellets, J. Apic. Res. 25, 53-54.

Milne C.P. Jr., Hellmich R.L., Pries K.J. (1986) Corbicular size in workers from honeybee lines selected for high or low pollen hoarding, J. Apic. Res. 25, 50-52.

Nye W.P., Mackensen O. (1968) Selective breeding of honey bees for alfalfa pollination: fifth generation and backcross, J. Apic. Res. 7, 21-27. 
Nye W.P., Mackensen O. (1970) Selective breeding of honey bees for alfalfa pollen collection: with tests in high and low alfalfa pollen collection regions, J. Apic. Res. 9, 61-64.

Page R.E. (1999) Commercial management of honey bees for pollination, in: 36th Apimondia Congress Proc., Vancouver, Canada, pp. 124-125.

Page R.E., Erber J., Fondrk M.K. (1998) The effect of genotype on response thresholds to sucrose and foraging behavior of honey bees (Apis mellifera L.), J. Comp. Physiol. A 182, 489-500.

Page R.E., Fondrk M.K., Hunt G.J., Guzman-Novoa E., Humphries M.A., Nguyen K., Greene A.S. (2000) Genetic dissection of honeybee (Apis mellifera L.) foraging behavior, J. Hered. 91, 474-479.

Robbertse H., Johannsmeier M.F., Morudu T.M. (1998) Pollination of 'Hass' avocados, S. Afr. Avocado Growers’ Assn. Ybk. 21, 63-68.

Schaffer A.A., Nerson H., Zamski E. (1991) Premature leaf chlorosis in cucumber associated with high starch accumulation, J. Plant Physiol. 138, 189-190.

Schmid-Hempel P., Kacelnik A., Houston A.I. (1985) Honeybees maximize efficiency by not filling their crop, Behav. Ecol. Sociobiol. 17, 61-66.

Shafir S., Afik O. (2001) The effect of ambient temperature on crop load size in honey bees, in: Sommeijer M., de Ruijter A. (Eds.), Proc. of the specialists' meeting on insect pollination in greenhouses, Soesterberg, The Netherlands, pp. 155-161.

Sokal R.R., Rohlf F.J. (1995) Biometry, 3rd ed., W.H. Freeman, San Francisco, 887 p.

Southwick E.E., Roubik D.W., Williams J.M. (1990) Comparative energy balance in groups of Africanized and European honey bees: ecological implications, Comp. Biochem. Physiol. 97A, 1-7.

Stern R.A., Eisikowitch D., Dag A. (2001) Sequential introduction of honeybee colonies and doubling their density increase cross-pollination, fruit set and yield in 'Red Delicious' apple, J. Hortic. Sci. Biotech. 76, 17-23.

Stout A.B. (1923) A study in cross-pollination of avocados in Southern California, Calif. Avocado Assoc. Annu. Rep. 1922-1923, 29-45.

Vithanage H.I.N.V. (1990) The role of the European honey bee (Apis mellifera L.) in avocado pollination, J. Hortic. Sci. 65, 81-86. 